\title{
ROUTINE CHANGE AND TRANSFORMATIONAL CHANGE MANAGEMENT AS DETERMINANTS OF TEACHERS' COMMITMENT IN SECONDARY SCHOOLS IN CALABAR EDUCATION ZONE, NIGERIA
}

\author{
Enoh Bassey Ekpenyong \\ Department of Educational Management, \\ Faculty of Education, \\ P.M.B 1115, University of Calabar, Calabar, Nigeria \\ Email: enohekpenyong@gmail.com \\ $+2347034928259$
Adewale Babatope Oduntan (Corresponding author)
Department of Educational Management, Faculty of Education,
P.M.B 1115, University of Calabar, Calabar, Nigeria
Email: adedollar1@yahoo.com
$+2348036541934$

\begin{abstract}
The thrust of this study was to examine routine change and transformational change management as determinants of teachers' commitment in secondary schools in Calabar Education Zone of Cross River State, Nigeria. Two null hypotheses were formulated to guide the study. The study made use of survey research design. The sample of the study comprised 634 teachers selected from a population of 2,112 teachers' using stratified random sampling technique. The instrument for data collection was developed by the researchers and titled: "Routine Change and Transformational Change Management as Determinants of Teachers' Commitment Questionnaire (RCTCMTCQ)'.The data collected were subjected to statistical analysis using Simple linear regression analysis. The hypotheses were tested at .05 level of significance. The results of the study revealed that routine change management and transformational change management significantly determine teachers' commitment in secondary schools in Calabar Education Zone of Cross River State, Nigeria. Based on the findings of the study, it was recommended among others that school leaders should ensure that the method and practice of routine change management is adhered to in order to evade role conflict at reaching the anticipated goals in the school system.
\end{abstract}

KEYWORDS: routine change, transformational change, teachers' commitment, secondary schools

\section{INTRODUCTION}

The place of teachers in any educational institution of teaching-learning cannot be exaggerated. This is predicated on the crucial role they play as implementers of the 
British Journal of Education

Vol.8, Issue 7, pp.44-56, August 2020

Published by ECRTD- UK

Print ISSN: ISSN 2054-6351: Online ISSN: ISSN 2054-636X

curriculum at the classroom level. This explains that what teachers do or do not do could directly or indirectly affect the attainment of instructional objectives in the classroom. Consequently, scholars have often attributed students' learning outcome to certain teacher attributes. It can be said that the extent to which a school achieves intended objectives, depends on the level of job commitment displayed by the teachers. In Calabar Education zone, observation by the researchers shows that the position of teachers' commitment has been in serious doubt due to the attitudes manifested by several secondary school teachers. Majority of the secondary school teachers do not appear to be committed to their jobs as evidenced in their poor punctuality attitudes to school and classes. In fact, some have become lukewarm in giving students note and assignment after lessons. Some teachers have also been observed using lesson periods for unnecessary discussion in the staffroom. The menace of teachers' poor commitment in the State has been on the high strain in the academic system and cannot be overstressed. The situation is unacceptable and cannot guarantee or contribute to students' academic growth, and has further raised the eyebrows of many curious stakeholders. Adetula (2005:34) opined that the state of affairs in our secondary schools where in his words "a totally unwholesome and non-professional behaviour of teachers such as absenteeism, lateness, malingering, trading and the general low level of commitment to duty which appears to be indices of lack of or poor management in school administration". Given this scenario in the school, it is the duty of the principal to coordinate such activities through effective management, without which, effective teaching may not be accomplished easily. The responsibilities of principals as managers of secondary schools is one that teachers and students stand to benefit from in the application of the changes derivable from effective management. Since the job of the principals is indispensable and enormous, it requires that teachers work towards the exhibition of their commitment to realize the envisioned school goals and objectives. Hence, it therefore becomes imperative that the services of proficient and qualified managers and devoted teachers be sought for to effect the changes that is gradually creeping into the school system.

Principals' are saddled with numerous responsibilities in the administration of secondary schools. The office of a principal is an administrative position considered to be highest in hierarchy of authority in secondary school which is occupied by a person charged with the tasks of planning, controlling and coordination of human, material, financial and time resources which are all the function of management to foster the attainment of the school goals and objectives. The school principal as the instructional leader is entrusted with the responsibility of improving the quality of instructional delivery through adequate management of change. In view of this, Ugboka (2012) stated that the school principals are the managers whose responsibility is to provide variety of supervision techniques for teachers to see the need for change, plan for change and practice new behaviour for effective teaching and learning. Ekpenyong (2018) viewed change management as signifying the modifications of schedules in the structure or technologies of organizations, programme, procedures or new ways of doing things to replace, adjust, correct, lift, promote and bring up the situation of such things to the desired position in order to meet with the developmental needs of a society arising from the commitment of the individual 
British Journal of Education

Vol.8, Issue 7, pp.44-56, August 2020

Published by ECRTD- UK

Print ISSN: ISSN 2054-6351: Online ISSN: ISSN 2054-636X

workers. Akpan, Ekpenyong and Oduntan (2019) posited that such changes may include but not limited to workers' attitudes, obligations, time, energy, transparency, loyalty and other services to show their commitments. Similarly, other changes may be extension of the manned hours which may call for extra remuneration for the teachers; such as overtime, lesson fees where extra lessons are organize for students thereby indicating an adjustment in their job schedule. Regrettably, there have been some complaints from various quarters on the failure of some school principals to put to action the required change management practices that would have guaranteed optimal commitment on the path of the teachers. It may therefore not be negating to state that the lack of commitment and poor job performance in schools may not be unconnected with this observed laxity of principals.

Based on these, it has become imperative that principals' must be adequately positioned and trained for the effective and efficient management of change to elicit teachers' commitment. For teachers to perform their task creditably, they need to make use of the change tools in the discharge of their routine duties in order to help transform the schools to conform to global best practices. Principals as the managers of change also need to have adequate knowledge in the applicability of change to connect with the global trend of efficiency and effectiveness. The availability and use of the change outfits can be used by the teachers and principals in transacting duties easily in areas such as school lesson plans, curriculum, students' data processing, record keeping and meeting the needs of urgent routine activities if properly and well managed. It is against this background that the researchers were interested to examine the extent to which routine change and transformational change management determines teachers' commitment in secondary schools in Calabar Education Zone of Cross River State, Nigeria.

\section{Statement of the problem}

There is no gain saying the fact that in ideal circumstance, teachers were expected to perform their duties with a high level of value in order to make easy the attainment of school goals and objectives. The primary duty of every secondary school teacher is to modify learners' behaviour in order to become useful to themselves and society in general. Unfortunately, in reality, quite a number of teachers have been found to be ineffective in their job and show low commitment as displayed in their poor attitude to work, poor record keeping habit, unpunctuality to school, irregular attendance in classes, teaching without prescribed instructional materials, not marking the attendance register regularly and several other unacceptable behaviour which are inimical to the growth of the school system. These have been an issue of concern with the government and all relevant stakeholders making efforts to mitigate this problem. The source of the problems associated with this action is yet to be ascertained. It is against this backdrop that this study seeks to investigate routine change and transformational change management as determinants of teachers' commitment in secondary schools in Cross River State, Nigeria. 
British Journal of Education

Vol.8, Issue 7, pp.44-56, August 2020

Published by ECRTD- UK

Print ISSN: ISSN 2054-6351: Online ISSN: ISSN 2054-636X

\section{Purpose of the study}

The purpose of the study was to investigate routine change and transformational change management as determinants of teachers' commitment in secondary schools in Cross River State, Nigeria. Specifically, the study aimed at finding out whether:

1. Routine change management determine teachers' commitment in secondary school in Calabar Education Zone of Cross River State, Nigeria

2. Transformational change management determine teachers' commitment in secondary school in Calabar Education Zone of Cross River State, Nigeria

\section{Statement of hypotheses}

The study was directed by the following hypotheses:

1. Routine change management does not significantly determine teachers' commitment in secondary school in Calabar Education Zone of Cross River State, Nigeria

2. Transformational change management does not significantly determine teachers' commitment in secondary school in Calabar Education Zone of Cross River State, Nigeria

\section{LITERATURE REVIEW}

\section{Routine change management and teachers' commitment}

Routine change management is described as a day-to-day change. According to Alimba (2009), it is a kind of change management which does not necessarily need planning. Kenny (2003) posited that routinization or routine change management occurs when innovation becomes part of normal operational activities in a school or an organization. Routine change management therefore features mostly in everyday activities involving administrative procedures. This may involve the adjustment in the school time-table, meeting schedule, inclusion of change and innovation processes, time allotted for extra lessons, reporting and closing time, its implementation which may subsequently drive towards influencing teachers' commitment. For teachers to be committed to routine change, their commitment must be based on reward and recognition to avoid resistance, Andrew (2004). Routine change management gives credence to changes in our schools. Nickols (2016) based this on the ability to plan, initiate, realize, control and at the end stabilize the processes of change on corporate and individual levels. Change has no exception, it moves steadily in an ongoing process, which comprises revolution, evolution, transformation, innovation and coupled with routines. Change is the continuous adoption of corporate strategies and structures to changing external conditions. Today, change management has no exception but moves in a steady ongoing process. Change management solidly comprises, revolutionary one-off projects, evolutionary, transformations and routines which may follow designed processes and school record keeping as a strategy through ICT for effective management. 
British Journal of Education

Vol.8, Issue 7, pp.44-56, August 2020

Published by ECRTD- UK

Print ISSN: ISSN 2054-6351: Online ISSN: ISSN 2054-636X

Aloysius, Ifreke and Margaret (2014) examined the extent and factors militating against the use of ICT as an affective and effective strategy for the management of school records in Akwa Ibom State, 145 school principals were selected out of 228 to respond to the instrument used. Frequency counts and percentages were used in analyzing the data. The result of this research indicated that the level of utilization of ICT for school record keeping meant to change the old method was low, and that the use of ICT in school changes helps school administrators cum principals to cope with sudden information increase and processing of data with greater speed and accuracy. In their recommendation, they stated that Akwa Ibom Government should provide ICT facilities to all public secondary schools in the state and train the principals and teachers on the use ICT facilities to bring about the desired changes in our secondary schools. In a study carried out by Bassey (2009) seeking to know the level of resistance to effective plan implementation of Universal Basic Education (UBE) programme in Akwa Ibom State. The scholar chooses two local government areas: Uyo and Abak. The population of 2,071 teachers was used showing 200 and $9.69 \%$ of teachers in the two local government areas. Stratified random approach was used. The findings showed that efforts should be intensified to improve on the level of commitment so as to allow a high level of implementation of change management to be experienced in secondary schools scheme indicating that the more training is given to principals and teachers, the higher the level of their commitment to their institutions. This gains support in the work of Michaels (2009) which states that innovation implementation describes the process by which employees cum teachers become capable and committed to using a particular innovation resulting from their training.

Routine change management entails those changes in our schools which occur regularly, such as time management which may not be based on adequate planning. As teachers attempt to adjust to the expansion of their work lives, they are also investing an increasing amount of what was once thought of as personal time of professional responsibilities. Routine change management is faced by several constraints such as: inadequate training of staff to catch up with situational change, mismanagement of funds to sustain the change, inadequate infrastructure, and political instability, inability of the school administrators to manage the change, inadequate timing and inappropriate skilled manpower. These situations may bring about resistance and barriers. Change management has a better chance to succeed if it is accorded with existing structures, attitudes, values and norms which are routine in nature. A school principal must not rush in the implementation of planned or routine changes to avoid the disorganization of existing structures, values and norms but rather he should work within them as much as possible. The principal should note that for a change management strategy to spur the teachers to commitment, he must prove the need and benefit of the change, recognizing possible barriers and considering adequate means in managing the change though most of the change managers are not conversant with change management strategies. The principal should also bring the teachers into the implementation of the change to reduce resistance. 
British Journal of Education

Vol.8, Issue 7, pp.44-56, August 2020

Published by ECRTD- UK

Print ISSN: ISSN 2054-6351: Online ISSN: ISSN 2054-636X

Blumberg and Greenfield cited in Kulkani (2011), on school climate and teachers' motivation used a sample of 650 school teachers selected from 68 secondary schools in Ghana. The research design used was Ex-post facto research design. A well validated research instrument titled "School Climate and Teachers' Motivation Questionnaire (SCTMQ)" was used for the collection of data for analysis. Research findings showed that teachers were not motivated and spurred up to commitment by the change managers but by moral commitment. They suggested that much care should be attached to the management of change by the principals in the exercise of their authority in order to achieve the expected school goals and objectives. This study is in consonance with Bassey (2009) seeking to know the level of resistance to effective plan to the implementation of change management. This also gains support by Nickols (2016) which states that change management is the ability to plan, initiate, realize, control and at the end stabilize the processes on corporate and individual levels. Hence, routine change management does not necessarily need planning but is built on the day-to-day affairs of the school. The principal therefore must be able to apply the needed change gadgets to spur up the teachers to their commitment in their daily activities for the achievement of the school goals. It is therefore noted that the high handedness of teachers by the school principals could present some adverse condition if teachers are coerced beyond their willingness to show their commitment in the daily routine or certain day-to-day activities in the school organization. Hence, teachers should be well managed to hold them to show full commitment in their performances.

\section{Transformational change management and teachers' commitment}

Transformational change is changes which complete the shape or character of existing patterns or practices. The capacity of a principal's choice for change management falls on: changing people, changing structure, changing technology and allowing them to work for the achievement of the school goals. The principal therefore needs to manage these changes properly in order to influence the commitment of teachers or employees. According to Oboegbulam and Onwurah (2011), transformational change management results from the transformational leadership skill together with the training of staff and their commitment to compare with the level of performance leading the organization or school to the expected level of excellence. Hechanova and Olpoc (2013) noted that there are differences on the nature of influence of leadership and change management on employee commitment to change. Transformational leadership is widely assumed to play a major role in the promotion of school improvement efforts and educational change. Leithwood and Sleegers (2006) submitted that transformational leadership aims at helping teachers to develop themselves and foster personal commitment to the organizational goals of the school in order to change the practices of teachers and the school. The principal is expected to agitate the training of teachers to cope with the new policies to boost their commitment. Transformational change management also embraces change arising from innovations as of the frontier of knowledge exhibited by trained workers or committed teachers helping to transform a school or organization to the desired standard in addition to promote teachers' retention. Similarly, Okon and Essien (2014) stated that educational leaders are being presented with several models for improving the 
British Journal of Education

Vol.8, Issue 7, pp.44-56, August 2020

Published by ECRTD- UK

Print ISSN: ISSN 2054-6351: Online ISSN: ISSN 2054-636X

commitment of teachers in relation to classroom instruction and increasing students' achievement that advocate for better use of data to guide decisions about instruction. Hence, the training and retraining of teachers is a necessity for the derivation of good result in the management of change.

In a study carried out by Beverborg, Sleegers and Veen (2015) in the context of Vocational Educational Training (VET) colleges, using a survey among 447 VET teachers working in its teams, showing that transformational leadership has been identified as critical for the facilitation of teacher learning through training. The data for the study was collected and conducted in interdisciplinary teams of 6 VET colleges in 4 levels representing certain amount of mastery of an occupation. Convenience sampling method was used to obtain a sample as large as possible. The VET colleges were contacted via their board of directors. The responses were increased by providing the teachers' information about the aim of the study, the content of the questionnaire offered them a representation of the main findings in 4 of the 6 VET colleges. The findings therefore revealed that the possibility of a reciprocal relation between goal interdependence and social learning is therefore worthy of further exploration in future. It was also realized that teachers' practices significantly influence the engagement of teacher in their commitment and their professional development activities but differently than expected. It further revealed that with the formulation of a clear and shared vision, the transformational school teacher can inspire teachers to formulate, identify with, commit to and strive to realize school goals as considered by Thoonen, Sleegers, Oort, Peetsman and Geijsel (2011). The context of this work indicates specific findings in two different paths linking transformational practices, goals and task independence in springing up the commitment of teachers and organizational goals.

Ashkenas (2015) sees transformation as a different animal from change management and must be properly managed. The author noted that unlike change management, transformational change management does not focus on a new discrete, well-defined shift, but on a selection of ideas brought into the organization. It is worthy of note that transformational change management goal is not just the implementation of defined change; rather it puts the organization in a new pedestal, pursuing the vision of the future and influencing the commitment of employees for the attainment of the schools' objectives. Hence, technological innovation has contributed globally for the connection of the entire world bringing in transformation in different spheres and it must be properly managed (Ogunsolo \& Hezehich, 2005). This is in line with Ajayi (2000) who asserts that revolution taking place in Information Communication Technology (ICT) has been the central driving force for the global link processes bringing in transformation in different spheres. Change management benefits in areas with technology, resources, contacts, transformation and gains access to the achievement of organizational goals and employee's commitment helping to transform the entire organization or school. Studies have shown that the management of technological situations has changed the pedagogical roles of teachers and a compelling rationale for using technologies, particularly the ICT, internet, e-mail, e-learning which are fast emerging into the global range to change the 
British Journal of Education

Vol.8, Issue 7, pp.44-56, August 2020

Published by ECRTD- UK

Print ISSN: ISSN 2054-6351: Online ISSN: ISSN 2054-636X

state of affairs of organizations (Hepp, Hinestroza, Laurel, \& Rehbien 2004). These are changes which need to be managed effectively to support and transform the educational practice and requires careful planning and training of staff to fit into the processes of change emanating from the use of technologies to help transform the system and contribute to the advancement of innovation (Burbules \& Callister, 2000). Essien, Ajake and Ojini (2010) investigated ICT access, (as technological and transformational change implication) utilization as an instigator of school climate change adopted a process to arrive at the results and findings. Pearson Product Moment correlation analysis was adopted using survey research design. South-South geo-political zone of Nigeria was selected with a population of 8,141 students from 13 universities. The breakdown showed that 504 students were selected from 2 federal universities, 308 from states' university and 188 from private universities. The findings revealed a significant relationship between availability of ICT as a technological change and school climate change gives meaning that technological and transformational change management, if properly managed influence teachers' commitment. This is consistent with what Ashkenas (2015) asserts that transformation is a different animal and needs to be managed properly. This accepts what Geijsel, Sleegers, Leithwood and Jantzi (2003) posited that transformational effects on the commitment of teachers and effort towards school reform help the teachers to show their willingness to be committed to school reforms. Truly, if transformational change is properly implemented and the processes of change management followed, the use of technology will boost a global change culminating in the influence of teachers' commitment which may be spurred up by the availability of the needed facilities.

\section{METHODOLOGY}

The study deployed survey research design. This design involves the collection of data to accurately and objectively describe the existing phenomenon. The design was chosen on the principle that it helped in the determination of the nature of the situation during investigation. The population of the study comprised all the 2,112 teachers of public secondary school in the State. Stratified random sampling and purposive sampling techniques were used in the study. The sample comprised 634 teachers drawn from 81 public secondary schools in the 7 Local Government Areas of Cross River State, Nigeria. A research instrument was developed by the researchers' and entitled: "Routine Change and Transformational Change Management as Determinants of Teachers' Commitment Questionnaire (RCTCMTCQ)" and used for data collection. The questionnaire had only section A which contained twenty (20) items to measure the two dimensions of change management and teachers' commitment variables identified in this study. Each dimension was measured using 10 items of a modified 4-point Likert rating scale, ranging from Strongly Agree (SA), Agree (A), Disagree (D) and Strongly Disagree (SD) response options. The subjects were required to tick one of the response choices against an item to indicate the extent of their agreement or disagreement with the item. The instrument was face validated by experts in Measurement and Evaluation. The data collected were subjected to statistical analysis using Simple Linear Regression Analysis at .05 level of significance. 
British Journal of Education

Vol.8, Issue 7, pp.44-56, August 2020

Published by ECRTD- UK

Print ISSN: ISSN 2054-6351: Online ISSN: ISSN 2054-636X

\section{RESULTS/FINDINGS}

Hypothesis one

Routine change management does not significantly determine teachers' commitment

Table 1: Simple linear regression analysis of routine change management as determinants of teachers' commitment

$\mathrm{R}=.520, \mathrm{R}^{2}=.27$, Beta $\mathrm{wt}=.520$

\begin{tabular}{lrrrrr}
\hline Source of variation & SS & df & MS & F-ratio & p-level \\
Regression & 1165.21 & 1 & 1165.210 & $229.916^{*}$ & $.000^{\mathrm{b}}$ \\
& 0 & & & & \\
Residual & 3137.08 & 619 & 5.068 & & \\
& 0 & & & & \\
Total & 4302.29 & 620 & & & \\
& 0 & & & &
\end{tabular}

Table 1 indicates that at .05 level of significance and degrees of freedom 1 and 619, the critical F-ratio is 3.85. The calculated F-ratio obtained in establishing the influence of routine change management on teachers' commitment is $229.92(\mathrm{p}<.05)$. The calculated Fratio was seen to be greater than the critical F-ratio with the obtained significant value less than .05 level of significance used in the study. With these results, the null hypothesis which stated that there is no significant influence of routine change management on teachers' commitment was rejected. It was accepted alternately that there is significant influence of routine change management on teachers' commitment in secondary schools. The $\mathrm{R}$ which is the correlation coefficient of the independent and the dependent variables was 0.52 indicating significant positive influence on the independent and the dependent variables. This showed that as routine change management increases, teachers' commitment also increases. Hence, the correlation between the two variables, routine change management and teachers' commitment was moderate. The coefficient of determination $\left(\mathrm{R}^{2}\right)$ which explains the power of the independent variable in influencing the dependent variable is 0.27 . This showed that up to 27 percent of variance in teachers' commitment is explained by routine change management. This indicated that adequacy in routine change management will increase teachers' commitment to a reasonable extent in secondary schools.

Hypothesis two

Transformational change management does not significantly determine teachers' commitment 
British Journal of Education

Vol.8, Issue 7, pp.44-56, August 2020

Published by ECRTD- UK

Print ISSN: ISSN 2054-6351: Online ISSN: ISSN 2054-636X

\begin{tabular}{|c|c|c|c|c|c|}
\hline Source of variation & SS & df & MS & F-ratio & p-level \\
\hline Regression & 1161.50 & 1 & $\begin{array}{c}1161 . \\
50\end{array}$ & $228.91 *$ & $.000^{\mathrm{b}}$ \\
\hline Residual & 3140.79 & 619 & 5.07 & & \\
\hline Total & 4302.29 & 620 & & & \\
\hline
\end{tabular}

Table 2 shows that at .05 level of significance and degrees of freedom 1 and 619 , the critical F-ratio is 3.85. The calculated F-ratio obtained in establishing the influence of transformational change management on teachers' commitment is $228.91 \quad(p<.05)$. The calculated F-ratio was seen to be greater than the critical F-ratio with the obtained significant value less than .05 level of significance used in the study. With these results, the null hypothesis which stated that transformational change management does not significantly influence teachers' commitment was rejected. It was accepted alternately that transformational change management significantly influence teachers' commitment in secondary schools. The $\mathrm{R}$ which is the correlation coefficient of the independent and the dependent variables was 0.52 indicating significant positive influence on the independent and the dependent variables. This showed that as transformational change management increases, teachers' commitment also increases. Hence, the correlation between the two variables, transformational change management and teachers' commitment was moderate. The coefficient of determination $\left(\mathrm{R}^{2}\right)$ which explains the power of the independent variable in influencing the dependent variable is 0.27 . This showed that up to 27 percent of variance in teachers' commitment is explained by transformational change management. This indicated that adequacy in transformational change management will increase teachers' commitment reasonably.

\section{DISCUSSION}

The result of data analysis for hypothesis one shows that routine change significantly determines teachers' commitment. The finding also revealed that there was a significant influence of routine change management and teachers' commitment to duty in secondary school. This findings suggests that the greater the routine change management the more committed the teachers are in their duties. This finding could be ascribed to the fact that routine change has globally become a necessary ingredient in improving work in organization and therefore secondary schools are not left out in the pursuit of applying routine change in the running of school to enhance teachers' commitment. The finding is 
British Journal of Education

Vol.8, Issue 7, pp.44-56, August 2020

Published by ECRTD- UK

Print ISSN: ISSN 2054-6351: Online ISSN: ISSN 2054-636X

also in agreement with the findings by Kenny (2003) who posited that routinization or routine change management occurs when innovation becomes part of normal operational activities in a school or an organization. The finding of this study agrees with the findings by Michaels (2009) which states that innovation implementation describes the process by which employees cum teachers become capable and committed to using a particular innovation resulting from their training. The result of this finding is line with the assertion of Nickols (2016) which states that change management is the ability to plan, initiate, realize, control and at the end stabilize the processes on corporate and individual levels.

The second finding of this study shows that transformational change management significantly determines teachers' commitment in secondary schools. There was also a significant influence of transformational change management and teachers' commitment. This presupposes that transformational change management is a persuasive dynamic in enhancing teachers' commitment to work in secondary schools. Henceforth, there is a strong link between transformational change management and teachers' commitment in secondary schools. The finding could be credited to the fact that many school leaders are becoming more aware of the transformational changes in schools because of the universal movement in the claim of transformation in managing schools. Novel changes are being led into the school syllabus and transformational management practices are being used in schools to enhance scholastic activities. The finding is also in agreement with the finding by Geijsel, Sleegers, Leithwood and Jantzi (2003) who posited that transformational effects on the commitment of teachers and effort towards school reform help the teachers to show their willingness to be committed to school reforms The finding of this study agrees with the findings by Okon and Essien (2014) that educational leaders are being presented with several models for improving the commitment of teachers in relation to classroom instruction and increasing students' achievement that advocate for better use of data to guide decisions about instruction. The result of this finding is line with the assertion of Oboegbulam and Onwurah (2011) who submitted that transformational change management results from the transformational leadership skill together with the training of staff and their commitment to compare with the level of performance leading the organization or school to the expected level of excellence.

\section{CONCLUSION}

Premised on the results of the study, it was concluded that routine change and transformational change management significantly determines teachers' commitment in secondary schools. The implication is that routine change as well as transformational change management can improve the way and manner at which teachers' perform their responsibilities which invariably accounts for their commitment. Consequently, proper change management in secondary schools is germane for better-quality of teachers' presentation. 
British Journal of Education

Vol.8, Issue 7, pp.44-56, August 2020

Published by ECRTD- UK

Print ISSN: ISSN 2054-6351: Online ISSN: ISSN 2054-636X

\section{RECOMMENDATIONS}

Arising from the findings of the study, it was recommended that:

1. School leaders should ensure that the method of routine change management is adhered to in order to evade role conflict at reaching the anticipated goals in the school system

2. Government should see to the need that school leaders undergo training and retraining in order to cope with the management of change for global relevance.

\section{REFERENCES}

Adetula, L. O. (2005). Improving the supervisory skills and competencies of inspectors of mathematics education in schools. International Journal of Teacher's Registration Council of Nigeria, 1(1), 33-40.

Ajayi, G. O. (2000). Challenges to Nigeria of globalization and the information age. Keynote Address of Workshop on National Information Communication Infrastructure (NICI) Policy: Plans and strategies for implementation. National Universities Commission (NUC) Auditorium. Aguyi Ironsi Street, Maitama, Abuja (March 28 - 30).

Akpan, C. P., Ekpenyong, E. B. and Oduntan, A. B. (2019). Change management variables as predictors of teachers' commitment in public secondary schools in Calabar Education Zone of Cross River State, Nigeria. Global Journal of Arts, Humanities and Social Sciences, 7(3), 1-13.

Alimba, C. N. (2009). Managing change in education. In J. B. Babalola \& A. O. Ayeni, (Eds). Educational management: theories and tasks. Ibadan: Macmillan Publishers.

Aloysius, S. N., Ifreke, U. A. and Margaret, E. S. (2014). Utilization of Information and Communication Technology (ICT) for school record keeping: A strategy for principals' management of secondary schools in Akwa Ibom State, Nigeria. Multidisciplinary Journal of Research Development, 22(1).

Andrew, D. (2003). The impact of perceived leadership behavior on satisfaction, commitment, and motivation: An expansion of the multidimensional model of leadership. International Journal of Coaching Science, 1(1), 35-56.

Ashkenas, R. (2015). We still do not know the difference between change and transformation. Harvard Business Review.

Bassey, S. U. (2009). Change management in education. In J. B. Babalola and A. O. Ayeni, (Eds). Educational management: Theories and tasks. Ibadan: Macmillan Publishers.

Beverberg, A. O. G., Sleegers, P. J. C. and Veen, K. V. (2015). Promoting vocational education and training (VET) teachers' individual and social learning activity, the empowering and purposeful leadership interdependence, and self-efficacy. Empirical Research in Vocational and Educational Training. Retrieved November 2016.

Burbules, N. C. and Callister, T. A. (2000). Watch it. The risks and promises of information technology for education. Westview, Colorado. 
British Journal of Education

Vol.8, Issue 7, pp.44-56, August 2020

Published by ECRTD- UK

Print ISSN: ISSN 2054-6351: Online ISSN: ISSN 2054-636X

Ekpenyong, E. B. (2018). Change management and teachers' commitment in Calabar Education Zone of Cross River State, Nigeria. Unpublished Master's Thesis, University of Calabar, Calabar.

Essien, M. I. E., Ajake, U. E. and Ojini, R. A. (2010). Information and Communication Technology, availability, access, utilization as instigators of school climate change. Nigerian Journal of Educational Administration and Planning, 10(3).

Geijsel, F. Sleegers, P., Leithwood, K. and Jantzi, D. (2003). Transformational effects on teachers' commitment and effort toward school reform. Journal of Educational Administrational Administration, 40(3), 228-256.

Hechanova, R. M. and Olpoc, R. C. (2013). Transformational leadership, change management and commitment to change: a comparison of academic and business organizations. Asia-Pacific Education Researcher, 22(1), 11-19.

Hepp, K. P., Hinosreoza, S. E., Laurel, M. E. and Rhbein, L. F. (2004). Technology in schools education, ICT and the knowledge society. Available at www.worldbank.org/education/pdf/ICTreportocl4a.pdf.

Kenny. J. (2003). A research-based model for managing strategic educational change and innovation projects. Melbourne. Australia: RMIT University.

Kulkani, A. (2011). What is participative management style? Retrieved: Nov. 10, 2015 from http://www.buggle.com/articles/types-of-leadership-styles-in-education.html

Leithwood, K. and Sleegers, P. (Eds.) (2006). Special issues of school effective and school improvement. Transformational school leadership 17(2). Retrieved November 15, 2016.

Michaels, B., Stegmaier, R. and Sonntag, K. (2009). Affective commitment to change and innovative implementation behavior: the role of charismatic leadership and employees' trust in top management. Institute of Psychology, Ruprecht. KarlsUniversity Heidelberg. Taylor \& Francis. Retrieved: March 2016.

Nickols, F. (2016). Four strategies for managing change. Retrieved: June 2016.

Oboegbulem, A. I. and Onwurah, C. U. (2011). Organization and management of education. A Nigerian perspective. Nigeria: Great AP Express Publishers Ltd.

Ogunsolo, L. A. and Hezehich, O. (2005). Information and communication technology and the effects of globalization: twenty-first century "digital slavery" for developing countries-myth and reality. Electronic Journal.

Okon, O. E. and Essien, M. I. (2014). School-based data and management of technological innovations in public secondary schools in Cross River State. Global Journal of Educational Research, 13, 55-123.

Thoonen, E. E. J., Sleegers, P. J. C., Oort, F. J., Peetsma, T. T. D. and Geijsel, F. P. (2011). How to improve teaching practices: The role of teacher motivation, organizational factors, and leadership practices. Educational Administration Quarterly, 47(3), 496-536.

Ugboko, F. E. (2012). A study of principals' supervisory strategies and secondary discipline. Journal of Education and Social Research, 2(1), 41-49. 